\title{
PENERAPAN MODEL PRAKTIKUM BERBASIS PROYEK DAN INQUIRI PADA MATERI HIDROKARBON DI KELAS XI SMA
}

\section{APPLICATION OF THE PROJECT BASED PRACTICUM MODEL AND INQUIRIES ON HYDROCARBON MATERIALS IN CLASS XI SMA}

\author{
Eva Pratiwi Pane**1, Fine Eirene Siahaan ${ }^{2}$ \\ ${ }^{1)}$ Program Studi Pendidikan Kimia, Universitas HKBP Nommensen Pematangsiantar \\ ${ }^{2)}$ Program Studi Pendidikan Fisika, Universitas HKBP Nommensen Pematangsiantar \\ *Corresponding author: evapratiwi2607@gmail.com
}

\begin{abstract}
ABSTRAK
Penelitian ini tentang penerapan model praktikum berbasis proyek dan inquiry pada materi hidrokarbon di kelas XI SMA. Tujuan dilakukannya penelitian untuk mengetahui hasil ketuntasan belajar, aktivitas siswa, dan tanggapan siswa selama pembelajaran berlangsung. Penelitian ini dilakukan menggunakan metode kualitatif deskriptif. Sampel pada penelitian ini, siswa kelas XI MIPA 2 berjumlah 30 siswa terdiri dari 14 siswa laki-laki dan 16 siswa perempuan. Teknik pengumpulan data dilakukan melalui tes tertulis, observasi aktivitas siswa, dan angket tanggapan siswa. Instrumen penelitian yang digunakan, yaitu lembar soal pilihan ganda (multiple chooise), lembar observasi aktivitas siswa, dan lembar angket tanggapan siswa. Hasil ketuntasan belajar sebesar 93,3\% (kategori baik sekali) dan siswa yang tidak tuntas sebesar $6,7 \%$ terdapat 28 siswa tuntas dan 2 siswa tidak tuntas. Hasil persentase observasi aktivitas siswa pertemuan kedua dan ketiga menunjukkan siswa belajar secara aktif selama pembelajaran menggunakan model inkuiri terbimbing sebesar $89,2 \%$ dan $80,75 \%$ (kategori baik sekali). Persentase tanggapan positif siswa melalui penerapan model inkuiri terbimbing selama pembelajaran pada materi asam basa sebesar 92,3\% (kategori sangat baik). Berdasarkan hasil dari penelitian ini, dapat disimpulkan bahwa penerapan pembelajaran melalui model praktikum berbasis proyek dan inquiry pada materi hidrokarbon di SMA Negeri 2 Pematangsiantar mencapai ketuntasan belajar secara klasikal meningkatkan aktivitas siswa, dan adanya tanggapan positif siswa terhadap penerapan model praktikum berbasis proyek dan inquiry.
\end{abstract}

Kata Kunci: Proyek; Inquiry; Hidrokarbon.

\section{ABSTRACT}

This research is about the application of a project-based and inquiry-based practicum model on hydrocarbon material in class XI SMA. The purpose of the study was to determine the results of complete learning, student activities, and student responses during the learning process. This research was conducted using descriptive qualitative method. The sample in this study, students of class XI MIPA 2 amounted to 30 students consisting of 14 male students and 16 female students. Data collection techniques were carried out through written tests, observation of student activities, and student response questionnaires. The research instruments used were multiple choice question sheets, student activity observation sheets, and student response questionnaire sheets. The results of complete learning are 93.3\% (very good category) and students who are not complete are $6.7 \%$, there are 28 students who complete and 2 students who do not complete. The results of the percentage of observations of student activities in the second and third meetings showed that students were actively learning during learning using the guided inquiry model of $89.2 \%$ and $80.75 \%$ (very good category). The percentage of students' positive responses through the application of the guided inquiry model during learning on acid-base material was 
92.3\% (very good category). Based on the results of this study, it can be concluded that the application of learning through a project-based and inquiry-based practicum model on hydrocarbon material at SMA Negeri 2 Pematangsiantar achieves classical learning completeness, increases student activity, and has positive student responses to the application of project-based and inquiry-based practicum models.

Keywords: Project; Inquiry; Hydrocarbon.

\section{PENDAHULUAN}

Pemerintah selalu berusaha untuk meningkatkan mutu pendidikan melalui berbagai kegiatan seperti pelatihan guru, perubahan dan penyempurnaan kurikulum, pemenuhan saran dan prasarana pendidikan, penerapan manajemen berbasis sekolah, sampai dengan tuntutan Undang-Undang Guru dan Dosen Tahun 2005. Akan tetapi Indikator ke arah peningkatan mutu pendidikan dirasakan lambat bila dibandingkan dengan tuntutan kemajuan IPTEK yang sangat cepat. Pendidikan harus dapat menyesuaikan diri dengan perubahan yang terjadi secara global sehingga peningkatan kualitas pendidikan harus selalu dilakukan secara terus menerus sesuai dengan situasi dan kondisi di Indonesia (Situmorang, 2013).

Pendidikan merupakan bagian terpenting yang dapat mendorong kemajuan manusia terutama dalam meningkatkan sumber daya manusia (SDM). Kimia merupakan salah satu dari beberapa mata pelajaran di sekolah yang dapat dijadikan sarana untuk mengembangkan kemampuan diri siswa, baik di bidang pengetahuan maupun keterampilan. Pembelajaran dapat dijadikan sebagai salah satu aktivitas belajar yang menekankan keterlibatan siswa secara aktif dan berusaha menemukan konsep sendiri sesuai tujuan pembelajaran. Model praktikum berbasis proyek dan inquiry dapat digunakan untuk melibatkan siswa secara aktif selama pembelajaran, baik dari proses mencari, menemukan hingga menarik kesimpulan dari apa yang dipelajari. Sehingga model praktikum dapat menunjang proses belajar dan hasil belajar menjadi lebih optimal. Proses ilmiah dapat dilakukan dalam waktu yang relatif singkat melalui rancangan pembelajaran dengan menerapkan model inkuiri terbimbing (Trianto, 2009). Siswa yang hanya belajar berdasarkan apa yang disampaikan oleh guru cenderung akan mendengarkan saja tanpa terlibat aktif secara langsung selama proses belajar. Materi pelajaran seperti asam basa akan lebih mudah dipahami jika dilakukan melalui pembelajaran yang melibatkan kemampuan siswa. Pembelajaran yang bersifat teacher center hanya akan mengakibatkan siswa melakukan sesuai apa yang diperintahkan. Kemampuan siswa dalam menyelesaikan masalah di dalam pembelajaran tidak terarah. Proses mencari dan menemukan adalah hal yang ditekankan dalam model praktikum berbasis proyek dan inquiry. Peran guru sebagai pembimbing dan fasilitator selama pembelajaran (Sanjaya, 2006). Menurut Suhendi (2011), ciri-ciri untuk dapat melihat hasil belajar yang diperoleh dilihat pada saat setelah proses belajar berlangsung. Siswa dapat memiliki kemampuan motorik, antara lain kemampuan menulis, mengetik, menggunakan alat-alat yang ada di laboratorium dan sebagainya.

Penerapan pelaksanaan pembelajaran kimia di sekolah pada materi hidrokarbon telah dilakukan melalui eksperimen, tetapi tidak semua siswa kelas XI melakukan eksperimen. Menurut salah seorang guru kimia di SMA Negeri 2 Pematangsiantar dalam wawancara yang telah dilakukan oleh peneliti bahwa perlakuan eksperimen yang dilakukan masih terbatas pada semua prosedur yang terdapat dalam buku dan siswa tidak terlibat untuk mengembangkan kemampuan dalam merancang eksperimen. Demikian juga dalam menyiapkan alat dan bahan, siswa hanya langsung menggunakan alat dan bahan yang telah disediakan tanpa ikut serta dalam penyiapannya. Penggunaan model praktikum disesuaikan dengan materi pelajaran yang akan menunjang hasil belajar menjadi lebih optimal. Pembelajaran materi hidrokarbon melalui model praktikum berbasis proyek dan inquiry akan menciptakan proses belajar yang mengutamakan aktivitas siswa. Sintak dalam praktikum berbasis proyek dan inquiry terdiri dari menyajikan pertanyaan dan masalah, membuat hipotesis, merancang percobaan, menguji hipotesis melalui percobaan untuk memperoleh informasi, mengumpulkan serta analisis data, hingga membuat kesimpulan (Trianto, 2009). Dimana, siswa diharuskan untuk melakukan eksperimen dan merancang langkah-langkah eksperimen sesuai kemampuan siswa yang dibimbing oleh guru. Oleh sebab itu, peneliti merasa perlu 
melakukan penelitian tentang Penerapan Model Praktikum Berbasis Proyek dan Inquiri Pada Materi Hidrokarbon Di Kelas XI SMA. Hasil penelitian melalui model pembelajaran inkuiri terbimbing telah dilakukan oleh Setiowati, Nugroho, dan Agustina dalam Meningkatkan Aktivitas dan Hasil Belajar Siswa diperoleh nilai rata-rata aktivitas belajar sebesar $80 \%$, dan ketuntasan belajar sebesar $84 \%$. Selanjutnya, penelitian oleh I Wayan, Fesy, dan Muhammad melalui model pembelajaran inkuiri terbimbing menunjukkan bahwa hasil belajar kognitif siswa sebesar 80,1. Siswa yang dibelajarkan melalui model inkuiri terbimbing memiliki kesempatan memperoleh pengalaman dan menemukan konsep bagi diri sendiri. Adapun tujuan penelitian ini, yaitu untuk mengetahui (1) Ketuntasan belajar siswa kelas XI SMA Negeri 2 Pematangsiantar setelah mengikuti pembelajaran menggunakan model praktikum berbasis proyek dan inquiry pada materi hidrokarbon; (2) Aktivitas siswa kelas XI SMA Negeri 2 Pematangsiantar selama mengikuti pembelajaran melalui model praktikum berbasis proyek dan inquiry pada materi hidrokarbon; dan (3) Tanggapan siswa kelas XI SMA Negeri 2 Pematangsiantar terhadap penerapan model praktikum berbasis proyek dan inquiry pada materi hidrokarbon. Manfaat dari penelitian ini, yaitu (1) bagi siswa, dapat meningkatkan hasil belajar selama proses pembelajaran berlangsung pada materi hidrokarbon; (2) bagi guru, dapat menjadi pertimbangan menentukan model pembelajaran guna meningkatkan hasil belajar siswa agar lebih optimal; (3) bagi sekolah, dapat menjadi tolak ukur dalam mengevaluasi kecakapan proses pembelajaran yang berlangsung di sekolah; dan (4) bagi peneliti, dapat memberikan informasi lebih dalam dan menumbuhkan wawasan tentang model pembelajaran inkuiri bebas pada materi hidrokarbon.

\section{METODE PENELITIAN}

\subsection{Jenis Penelitian}

Penelitian ini dilakukan menggunakan metode kualitatif deskriptif. Penelitian berfokus pada hasil ketuntasan belajar siswa, aktivitas siswa, dan tanggapan siswa terhadap penerapan model praktikum berbasis proyek dan inquiry pada materi hidrokarbon.

\subsection{Waktu dan Tempat Penelitian}

Penelitian telah dilakukan di SMA Negeri 2 Pematangsiantar, Kota Pematangsiantar, Provinsi Sumatera Utara. Waktu penelitian dilakukan sejak Januari-Maret 2020. Sampel yang digunakan pada penelitian ini adalah siswa kelas XI MIPA 2 SMA Negeri 2 Pematangsiantar yang berjumlah 30 siswa, terdiri dari 14 siswa laki-laki dan 16 siswa perempuan. Penentuan sampel penelitian dilakukan secara random sampling yang dipilih dari populasi dengan cara acak tanpa memperhatikan strata yang ada di dalam populasi (Sugiyono, 2010).

\subsection{Target/Subjek Penelitian}

Sampel yang digunakan pada penelitian ini adalah siswa kelas XI MIPA 2 SMA Negeri 2 Pematangsiantar yang berjumlah 30 siswa, terdiri dari 14 siswa laki-laki dan 16 siswa perempuan. Penentuan sampel penelitian dilakukan secara random sampling yang dipilih dari populasi dengan cara acak tanpa memperhatikan strata yang ada di dalam populasi (Sugiyono, 2010).

\subsection{Prosedur}

Teknik pengumpulan data dilakukan melalui hasil tes tertulis, hasil observasi aktivitas siswa, dan hasil angket tanggapan siswa. Pengumpulan data dilaksanakan pada lembar jawaban tes tertulis, lembar hasil observasi aktivitas siswa dengan memberikan tanda cek list $(\sqrt{ })$ pada kolom sesuai kriteria penilaian selama proses pembelajaran berlangsung, dan hasil angket tanggapan siswa yang telah diisi sebagai responden.

\subsection{Data, Instrumen, dan Teknik Pengumpulan Data}

Instrumen berperan penting dalam menentukan hasil penelitian. Instrumen memiliki fungsi dalam mengungkapkan suatu fakta yang telah diteliti melalui data yang dianggap akurat 
dan sahih untuk membuktikan kelayakan hasil penelitian. Instrumen dalam penelitian ini, yaitu (1) Lembar tes tertulis berupa soal pilihan ganda (multiple chooise) yang telah dinyatakan valid dan reliabel, serta telah diujicobakan di kelas XI SMA Negeri 2 Pematangsiantar, (2) Lembar aktivitas siswa selama pembelajaran berlangsung melalui penerapan model praktikum berbasis proyek dan inquiry akan dinilai oleh 3 orang observer, yaitu 1 orang guru mata pelajaran kimia dan 2 orang mahasiswa Program Studi Pendidikan Kimia FKIP Universitas HKBP Nommensen Pematangsiantar. Hasil observasi aktivitas siswa inilah yang nantinya akan menunjukkan bahwa model praktikum berbasis proyek dan inquiry efektif digunakan pada materi asam basa, dan (3) lembar angket tanggapan siswa berisi 20 pernyataan yang akan diberikan kepada siswa sebagai responden setelah proses pembelajaran selesai. Hasil angket tanggapan siswa akan menentukan apakah tanggapan positif atau negatif terhadap penerapan model praktikum berbasis proyek dan inquiry pada materi hidrokarbon.

\subsection{Teknik Analisis Data}

Analisis data tes tertulis dilakukan untuk mengetahui ketuntasan belajar siswa setelah diterapkan model praktikum berbasis proyek dan inquiry. Hasil tes tertulis di atas kemudian dihitung dengan rumus:

$$
\text { Nilai siswa }=\frac{\text { Jumlah jawaban benar }}{\text { Jumlah total soal }} \times 100 \%
$$

Selanjutnya, untuk mengetahui persentase ketuntasan belajar siswa dapat diperoleh mengunakan statistik deskriptif. Menurut Sudijono (2009), persentase ketuntasan klasikal dapat dihitung:

$$
\mathrm{P}=\frac{f}{N} \times 100 \%
$$

Keterangan:

$\mathrm{P}=$ Persentase

$\mathrm{f}=$ Jumlah siswa yang tuntas

$\mathrm{N}=$ Jumlah sampel

\section{HASIL DAN PEMBAHASAN}

Model praktikum berbasis proyek dan inquiry dilakukan berdasarkan kajian standar isi dan kompetensi dasar dengan merumuskan pembelajaran sehingga diketahui standar minimal yang akan dicapai kurikulum. Penelitian ini dilakukan untuk mengetahui hasil ketuntasan belajar siswa dan selama pembelajaran dilakukan observasi aktivitas siswa. Batasan materi pada pertemuan kedua tentang indikator hidrokarbon, dan merancang eksperimen identifikasi hidrokarbon hingga melakukan eksperimen.. Soal tes tertulis yang akan digunakan dalam penelitian ini telah divalidasi oleh validator ahli dan telah dujicobakan pada siswa kelas XI. Hasil persentase validasi soal tes tertulis sebesar $100 \%$, hasil persentase validasi lembar observasi aktivitas siswa sebesar $96,4 \%$ dan sebesar $100 \%$. Sedangkan hasil persentase validasi lembar angket tanggapan siswa sebesar $97,5 \%$ dan sebesar $100 \%$.

\subsection{Hasil Ketuntasan Belajar}

Data hasil ketuntasan belajar dalam penelitian ini ialah prestasi belajar siswa pada materi hidrokarbon untuk aspek kognitif. Untuk mengetahui hasil ketuntasan belajar siswa diberikan evaluasi di akhir pembelajaran melalui tes tertulis sebanyak 10 butir soal dalam bentuk pilihan ganda (multiple chooise). Tes tertulis yang diberikan sesuai dengan materi yang telah dipelajari melalui model pembelajaran inkuiri terbimbing. Berdasarkan hasil evaluasi yang didapat, dianalisis hasil belajar siswa untuk melihat ketuntasan belajar. Hasil ketuntasan belajar yang didapat dari 30 siswa di kelas XI MIPA 2, diketahui sebanyak 28 siswa tuntas dan 2 siswa tidak tuntas sesuai dengan nilai $\mathrm{KKM} \leq 70$ untuk mata pelajarankimia di sekolah.

Persentase hasil ketuntasan belajar melalui model praktikum berbasis proyek dan inquiry mencapai ketuntasan tinggi, yaitu sebesar 93,3\% tergolong kategori baik sekali, dan siswa yang tidak tuntas sebesar $6,7 \%$. Hasil ketuntasan belajar menunjukkan bahwa model praktikum berbasis proyek dan inquiry efektif digunakan pada materi asam basa. Persentase hasil ketuntasan belajar siswa dapat dilihat pada Gambar 1 . 


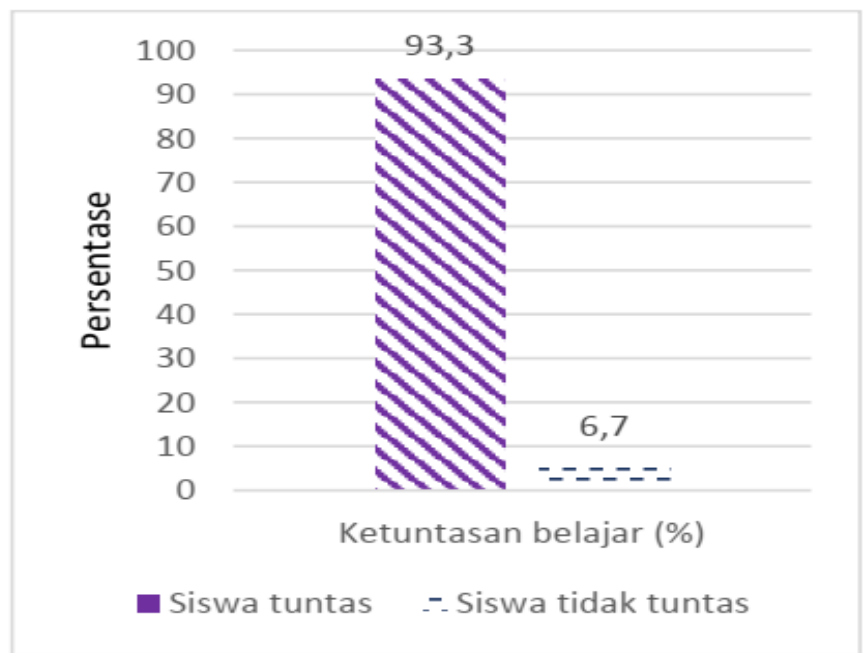

Gambar 1. Grafik Hasil Persentase Ketuntasan Belajar Siswa Kelas XI MIPA 2 SMA Negeri 2 Pematangsiantar

\subsection{Hasil Aktivitas Siswa}

Aktivitas siswa selama proses pembelajaran melalui penerapan model praktikum berbasis proyek dan inquiry berlangsung diperoleh melalui lembar observasi aktivitas siswa yang dinilai oleh 3 orang observer, yaitu 1 orang guru mata pelajaran kimia dan 2 orang mahasiswa Program Studi Pendidikan Kimia FKIP Universitas HKBP Nommensen Pematangsiantar. Ketiga observer mengamati aktivitas siswa pada pertemuan kedua dan ketiga. Setiap observer mengamati 2 kelompok selama pembelajaran berlangsung, karena jumlah kelompok yang dibentuk dalam penelitian ini adalah 6 kelompok dengan jumlah siswa tiap kelompok 5 orang. Data hasil pengamatan dari ketiga observer inilah yang digunakan sebagai hasil aktivitas siswa selama pembelajaran berlangsung.

Hasil observasi pertemuan kedua batasan materi yang disampaikan oleh peneliti dengan melakukan eksperimen di laboratorium. Observasi pertemuan kedua ini, siswa menyelesaikan tugas yang diberikan peneliti dalam bentuk LKS. Setiap siswa diarahkan oleh peneliti untuk menyelesaikan LKS dengan berdiskusi di dalam kelompok yang telah dibagikan secara heterogen. LKS berisi tentang pertanyaan yang membimbing siswa untuk membuat hipotesis sementara dan mengarahkan siswa untuk dapat merancang langkah-langkah eksperimen hingga melakukan eksperimen. Aktivitas siswa yang diamati oleh observer dimulai dari kegiatan pembuka, kegiatan inti, dan kegiatan penutup. Selanjutnya, hasil observasi yang telah dilakukan pada pertemuan kedua menunjukkan hasil persentase keaktifan siswa sebesar 89,2\% kategori baik sekali. Selama pembelajaran menggunakan model praktikum berbasis proyek dan inquiry, siswa belajar dengan berdiskusi dalam proses mencari, membuat hipotesis, menguji hipotesis, dan menarik kesimpulan dari permasalahan yang diberikan oleh peneliti. Sehingga pembelajaran mengakibatkan siswa terlibat langsung secara aktif dan saling bekerja sama untuk menyelesaikan tugas, dan menciptakan interaksi pembelajaran yang bersifat multi arah. Bahkan, bukan hanya aktivitas siswa yang dapat dinyatakan dalam kategori baik sekali, tetapi juga dapat menciptakan kemandirian siswa dalam menyiapkan kebutuhan pembelajaran seperti menyiapkan segala kebutuhan selama melakukan eksperimen di laboratorium, sehingga guru cukup berperan sebagai pembimbing dan fasilitator dalam pembelajaran.

Observasi pertemuan ketiga diamati oleh observer dan aktivitas yang diamati sama dengan aktivitas pada observasi pertemuan kedua, yaitu aktivitas siswa dari kegiatan pendahuluan, kegiatan inti, hingga kegiatan penutup. Observasi pertemuan kedua ini, siswa dibagikan LKS yang berisi pertanyaan dengan membuat hipotesis berupa persamaan yang dapat digunakan untuk menyelesaikan soal yang ada. Sehingga siswa didorong agar mampu menyelesaikan soal sesuai pemahaman dan kemampuan siswa. Berdasarkan hasil observasi pada pertemuan ketiga menunjukkan hasil persentase keaktifan siswa sebesar $80,75 \%$ kategori baik sekali. Nilai persentase keaktifan pada observasi pertemuan ketiga menurun dari 
persentase observasi pertemuan kedua, tetapi masih dalam kategori baik sekali. Penurunan persentase aktivitas siswa pada pertemuan ketiga terjadi karena materi pelajaran membahas yang identik dengan rumus-rumus kimia yang membutuhkan konsentrasi siswa untuk fokus secara maksimal. Sedangkan observasi tahap kedua baik sekali, siswa tampak senang dan terlihat lebih fokus karena materi yang disampaikan mengajak mereka untuk merancang dan melakukan eksperimen. Secara keseluruhan pembelajaran melalui model praktikum berbasis proyek dan inquiry tampak siswa saling berlomba baik dalam menanggapi, bertanya dan menjawab pertanyaan dalam menyelesaikan permasalahan. Sehingga tercipta suasana kelas yang tetap aktif dengan kategori baik sekali selama pembelajaran pada materi asam basa menggunakan model praktikum berbasis proyek dan inquiry. Persentase hasil observasi aktivitas siswa pertemuan kedua dan ketiga melalui penerapan model praktikum berbasis proyek dan inquiry dapat dilihat pada Gambar 2.

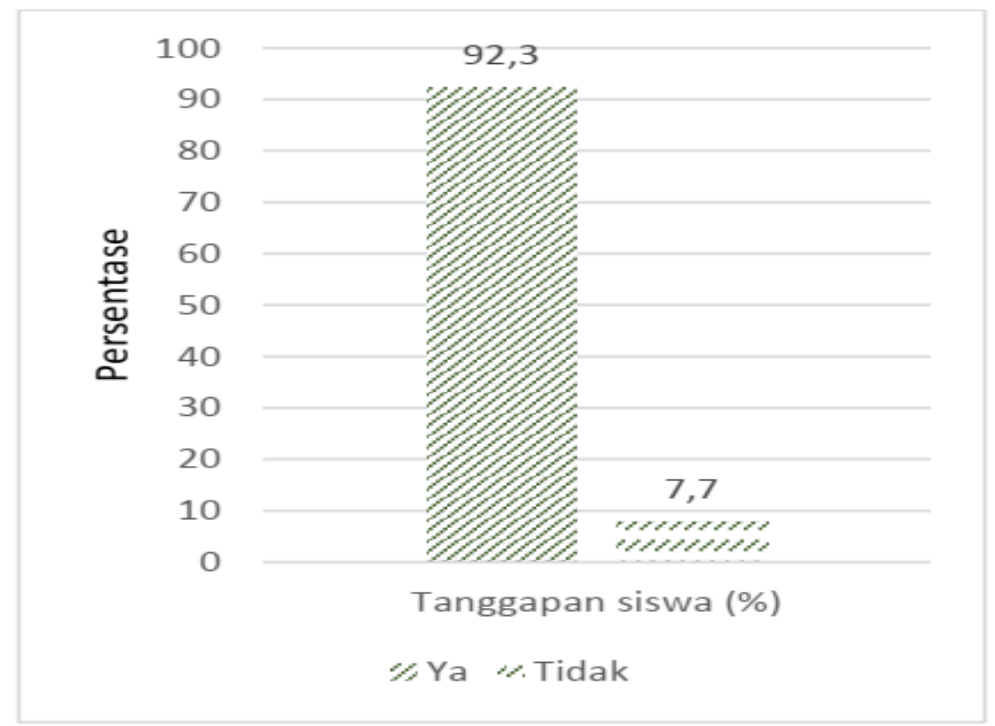

Gambar 2. Grafik Hasil Persentase Tanggapan Siswa Kelas XI MIPA 2 SMA Negeri Pematangsaintar

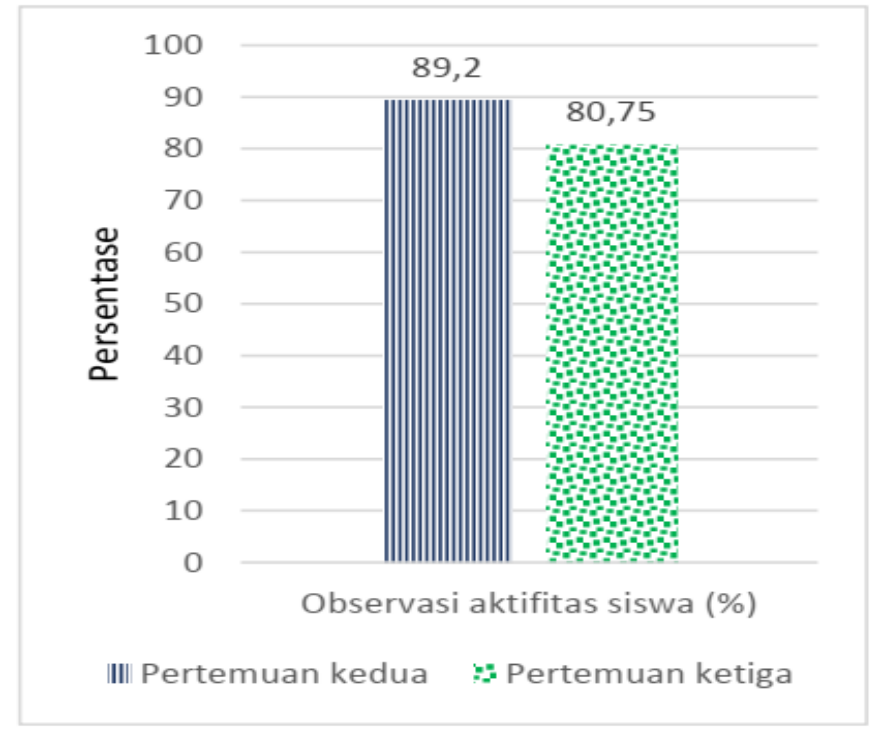

Gambar 3. Grafik Hasil Persentase Observasi Pertemuan Kedua dan Ketiga Siswa Kelas XI MIPA 2 SMA Negeri 2 Pematangsiantar 


\subsection{Hasil Angket Tanggapan Siswa}

Tanggapan siswa dinilai menggunakan angket yang berisi 20 pernyataan yang diberikan kepada siswa sebagai responden setelah pembelajaran melalui model praktikum berbasis proyek dan inquiry selesai. Angket diisi dengan menjawab pertanyaan melalui pilihan jawaban Ya/Tidak. Nilai persentase rata-rata tanggapan positif siswa yang memilih jawaban Ya terhadap penerapan model praktikum berbasis proyek dan inquiry sebesar 92,3\% (kategori sangat baik) dan tanggapan negatif yang memilih Tidak sebesar 7,7\%.

Berdasarkan data persentase yang diperoleh menunjukkan tanggapan positif siswa terhadap penerapan model praktikum berbasis proyek dan inquiry. Tanggapan positif yang paling banyak diberikan keseluruhan siswa pada pernyataaan angket nomor 2, 4, 5, 8, 16, dan 20. Dimana, siswa merasa yakin, mampu, dan bekerja keras selama proses belajar menggunakan model praktikum berbasis proyek dan inquiry. Hasil persentase tanggapan siswa terhadap penerapan model pembelajaran inkuiri terbimbing dapat dilihat pada Gambar 4.

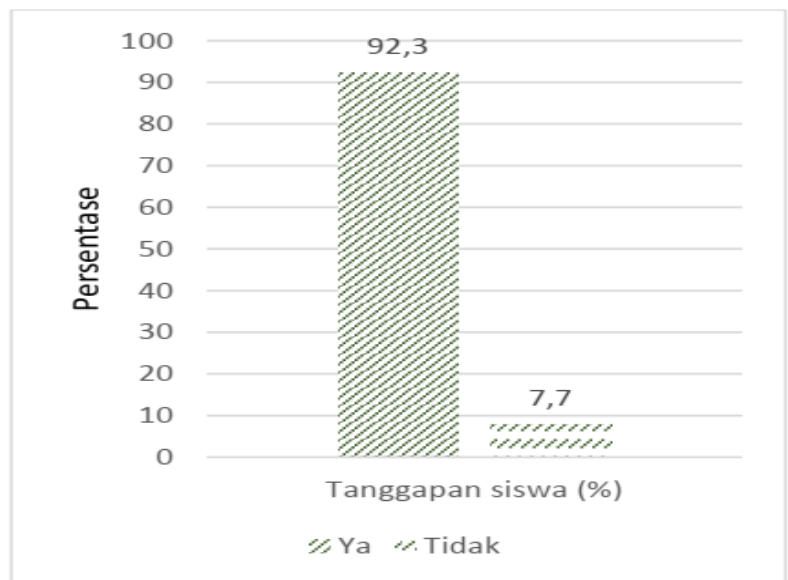

Gambar 4. Grafik Hasil Persentase Tanggapan Siswa Kelas XI MIPA 2 SMA Negeri 2 Pematangsiantar

\section{SIMPULAN DAN SARAN}

\section{1 Simpulan}

Berdasarkan data hasil penelitian dan pembahasan tentang penerapan model praktikum berbasis proyek dan inquiry pada materi hidrokarbon di kelas XI MIPA 2 SMA Negeri 2 Pematangsiantar dapat disimpulkan hal sebagai berikut:

1. Hasil ketuntasan belajar siswa didapat persentase siswa yang tuntas sebesar 93,3\% (kategori baik sekali) dan siswa yang tidak tuntas sebesar 6,7\%. Siswa kelas XI MIPA 2 yang terdiri dari 30 siswa diketahui terdapat 28 siswa tuntas dan 2 siswa tidak tuntas.

2. Hasil persentase observasi aktivitas siswa pertemuan pertama dan kedua menunjukkan siswa belajar secara aktif selama pembelajaran menggunakan model praktikum berbasis proyek dan inquiry sebesar $89,2 \%$ dan $80,75 \%$ (kategori baik sekali).

3. Persentase tanggapan positif siswa melalui penerapan model praktikum berbasis proyek dan inquiry selama pembelajaran pada materi hidrokarbon sebesar 92,3\% (kategori sangat baik).

\section{2 Saran}

Berdasarkan hasil penelitian dan kesimpulan, penulis menyarankan hal sebagai berikut: 
1. Bagi siswa, untuk terus berusaha dalam meningkatkan motivasi belajar agar lebih aktif serta dapat memahami materi pelajaran dengan baik sehingga hasil pembelajaran yang dicapai memuaskan.

2. Bagi guru, diharapkan untuk menggunakan model pembelajaran yang mendorong siswa agar lebih aktif selama pembelajaran sehingga proses belajar dan hasil belajar dapat diperoleh semaksimal mungkin.

3. Bagi peneliti selanjutnya yang ingin menerapkan model praktikum berbasis proyek dan inquiry, diharapkan agar lebih mendorong siswa dalam meningkatkan motivasi belajar.

\section{DAFTAR PUSTAKA}

Arikunto, S. (2010). Prosedur Penelitian Suatu Pendekatan Praktik. Jakarta: Rineka Cipta Hake, R. 1998. Interactive-Engagement Versus Traditional Methods: A SixThousandStudent Survey Of Mechanics Test Data For Introduvtory Physics Course. American Asosiation Of Physics Teachers. 66(1): 65-74.

Hendriyanto, J., dan Amaria. (2013). "Penerapan Model Pembelajaran Inkuiri untuk Melatih Kemampuan Berpikir Tingkat Tinggi Siswa pada Materi Pokok Laju Reaksi”. Unesa Journal of Chemical Education. Hal 151-158.

I Wayan, J., Fesy, M., dan Muhammad, S. (2013). "Penerapan Metode Pembelajaran Inkuiri Terbimbing untuk Mengingkatkan Hasil Belajar dan Sikap Ilmiah Siswa Kelas XI IPA Semester II SMA Negeri 5 Malang pada Materi Koloid”. Jurnal Kimia FMIPA. Hal 3-4.

Masruroh, S. (2014). Implementasi Pendekatan Scientific pada Kurikulum 2013 untuk Meningkatkan MotivasiBelajar Siswa pada Bidang Kompetensi Teknologi Informasi dan Komunikasi.Prosiding Konvensi APTEKINDO ke 7 FPTK UPI Bandung.

Pane, Eva Pratiwi. (2016) Pengembangan Bahan Ajar Kimia Inovatif Berbasis Multimedia Untuk Meningkatkan Hasil Belajar Siswa Pada Pengajaran Laju Reaksi. Masters thesis, UNIMED.

Sanjaya, W. (2006). Strategi Pembelajaran Berorientasi Standar Proses Pendidikan. Jakarta: Kencana.

Sardiman, A. (2005). Interaksi dan Motivasi Belajar Mengajar. Jakarta: Rajawali Pers.

Setiowati, H., Nugroho, A., dan Agustina, W. (2015). Penerapan Model Pembelajaran Inkuiri Terbimbing (Guided Inquiry) dilengkapi LKS untuk Meningkatkan Aktivitas dan Prestasi Belajar Siswa pada Materi Pokok Kelarutan dan Hasil Kali Kelarutan Kelas XI MIA SMA Negeri 1 Banyudono Tahun Pelajaran 2014/2015. Jurnal Pendidikan Kimia (JPK). Hal 54-60.

Situmorang, H. (2013). Efektivitas Metode Demonstrasi Dalam Meningkatkan Hasil Belajar Siswa Sekolah Menengah kejuruan Pada pengajaran Sistem Koloid. Jurnal Penelitian Bidang Pendidikan Volume 19(1): 28-36.

Sugiyono, (2010). Metode Penelitian Pendidikan (Pendekatan Kuantitatif, Kualitatif, dan $R$ dan $D)$. Bandung: Alfabeta.

Suhendi, R. (2011). "Penerapan Model Numbered Heads Together (NHT) pada Materi Konsep Mol Untuk Meningkatkan Hasil Belajar Kimia Siswa Kelas X di SMK Negeri 1 Banda Aceh”. Skripsi. Banda Aceh: Universitas Syiah Kuala.

Trianto. (2009). Mendesain Model Pembelajaran Inovatif-Progresif. Jakarta: Kencana Prenada Media Group. 